\title{
PENGARUH MODEL PEMBELAJARAN TGT (TEAMS GAMES TOURNAMENT) DENGAN SETING LESSON STUDY TERHADAP SIKAP ILMIAH SISWA
}

\author{
Ni. W. Karini ${ }^{1}$, A. A. G. Agung ${ }^{2}$, I M. Citra Wibawa ${ }^{3}$ \\ 1,2,3 Universitas Pendidikan Ganesha \\ e-mail: wayankarini30@gmail.com ${ }^{1}$, agung2056@undiksha.ac.id ${ }^{2}$, \\ imadecitra.wibawa@undiksha.ac.id ${ }^{3}$
}

\begin{abstract}
ABSTRAK
Sampai saat ini sikap ilmiah IPA siswa masih rendah. Rendahnya sikap ilmiah siswa dipengaruhi oleh banyak faktor, baik faktor internal dan faktor eksternal. Salah satu faktor eksternal yang dianggap berpengaruh adalah model pembelajaran. Oleh karena itu penelitian ini bertujuan untuk mengetahui pengaruh yang signifikan model pembelajaran TGT (Teams Games Tournament) dengan seting Lesson study terhadap Sikap IImiah Siswa Kelas IV SD Semester Genap di Gugus II Kecamatan Kubutambahan. Penelitian ini merupakan jenis penelitian quasi eksperimen dengan desain non-equivalent kontrol group design. Populasi pada penelitian ini adalah seluruh kelas IV SD di Gugus II Kecamatan Kubutambahan yang berjumlah 194 orang. Teknik pengambilan sampel pada penelitian ini dengan menggunakan teknik cluster random sampling. Sampel dalam penelitian ini yaitu SD Negeri 1 Kubutambahan sebagai kolompok eksperimen dan SD Negeri 6 Kubutambahan sebagai kelompok kontrol. Instrumen dalam mengumpulkan data menggunakan kuesioner yang berjumlah 30 butir pernyataan. Penskoran kuesioner menggunakan skala likert. Data yang diperoleh dianalisis menggunakan teknik analisis statistik deskriptif dan teknik analisis statistik inferensial (uji-t). Berdasarkan hasil analisis uji-t diperoleh $t_{\text {hitung }}$ sebesar 9,56 dan $t_{\text {tabel }}$ pada taraf siginifikansi $5 \%$ dengan $\mathrm{dk}=70$ adalah 1,99. Hal ini menunjukkan $t_{\text {hitung }}>\mathrm{t}_{\text {tabel }}$ sehingga $\mathrm{H}_{0}$ ditolak dan $\mathrm{H}_{1}$ diterima. Dengan demikian dapat disimpulkan bahwa terdapat pengaruh yang signifikan model pembelajaran TGT (Teams Games Tournament) dengan Seting Lesson Study terhadap sikap ilmiah siswa kelas IV Semester II di SD Gugus II Kecamatan Kubutambahan.
\end{abstract}

Kata Kunci : TGT (Teams Games Tournament), Lesson Study, Sikap Ilmiah

\begin{abstract}
Until now the scientific attitude of science students is still low. The low scientific attitude of students is influenced by many factors, both internal factors and external factors. One of the external factors that can affect the students' scientific attitude is learning model. Therefore this study aimed to investigate whether there was a significant effect of the TGT learning model with the setting of Lesson study on the Scientific Attitude of Class IV Students in Even Semester Schools in Group II of Kubutambahan District. The present study was type of quasi-experimental research with a nonequivalent control group design. The samples of this study were SD Negeri 1 Kubutambahan as an experimental group and SD Negeri 6 Kubutambahan as a control group. The instrument used for collecting the data was a questionnaire which amounts to 30 items. Questionnaire questionnaires used a Likert scale. The data were analyzed by using descriptive analysis and inferential analysis. The result showed that the $t$-test analysis obtained tcount of 9.56 and $t_{\text {table }}$ at the significance level of $5 \%$ with $d k=70$ is 1.99. This showed $t$ count $>t_{\text {table }}$ so that $H_{0}$ is rejected and $H_{1}$ is accepted. It can be concluded that there was a significant effect of the TGT learning model (Teams Games Tournament) with the Setting Lesson Study on the scientific attitude of the fourth grade students of Semester II in SD Group II in Kubutambahan District.
\end{abstract}

Keywords : Lesson Study, Scientific Attitude, TGT (Teams Games Tournament), 


\section{Pendahuluan}

Perkembangan zaman pada saat ini sangat membawa kita ke dalam arus perubahan yang sangat besar dalam segala aspek kehidupan maupun dalam aspek pendidikan dalam era globalisasi seperti sekarang. Pendidikan merupakan salah satu kebutuhan setiap manusia. Pendidikan mempunyai peranan penting dalam kelangsungan kehidupan manusia, karena melalui pendidikan dapat mengembangkan sumber daya manusia yang lebih berkualitas. Seiring dengan perkembangan zaman, sekarang di Indonesia sudah mencapai perkembangan industri 4.0. Istilah Industri 4.0 sendiri secara resmi lahir di Jerman tepatnya saat diadakan Hannover Fair pada tahun 2011 Kagermann dkk (dalam Prasetyo 2018). Beberapa negara lain juga turut serta dalam mewujudkan konsep industri 4.0 namun menggunakan istilah yang berbeda seperti Smart Factories, Industrial Internet of Things, Smart Industry, atau Advanced Manufacturing. Meski memiliki penyebutan istilah yang berbeda, semuanya memiliki tujuan yang sama yaitu untuk meningkatkan daya saing industri tiap negara dalam menghadapi pasar global yang sangat dinamis. Kondisi tersebut diakibatkan oleh pesatnya perkembangan pemanfataan teknologi digital di berbagai bidang Prasetyo (2018). Seiring dengan perkembangan zaman yang sudah memasuki industri 4.0 maka diperlukannya SDM yang bagus. Salah satu jalan agar sumber daya manusia bagus maka diperlukannya pedidikan yang baik, karena pendidikan sangat berperan penting agar dapat menjadi SDM yang mampu bertanggung jawab dan menjadi manusia yang demokratis.

Hal itu sejalan dengan tujuan pendidikan yaitu dalam Pasal 3 Undang-Undang Nomor 20 Tahun 2003 tentang Sistem Pendidikan Nasional disebutkan bahwa pendidikan nasional bertujuan untuk mengembangkan potensi peserta didik agar menjadi manusia yang beriman, berilmu, cakap, kreatif, mandiri, dan menjadi warga negara yang demokratis serta bertanggung jawab. Pendidikan tidak terlepas dari adanya kurikulum. Salah satu usaha pemerintah dalam meningkatkan mutu pendidikan adalah dengan adanya perubahan kurikulum sebagai pedoman dalam proses pembelajaran. Perubahan kurikulum pembelajaran dari KTSP menjadi kurikulum 2013. Dalam kurikulum 2013 proses pembelajarannya adalah berpusat pada siswa dan menuntut guru agar lebih kreatif dan inovatif dalam merancang kegiatan pembelajaran yang melibatkan peran aktif siswa. Ketentuan mengenai pengembangan kurikulum sebagaimana yang tercantum dalam (UU Nomor 20 tahun 2003) tentang Sistem Pendidikan Nasional, Pasal 37 Ayat 1 menyebutkan bahwa kurikulum pada jenjang pendidikan dasar dan menengah wajib memuat 10 mata pelajaran. Salah satu mata pelajaran di SD adalah IPA. IImu Pengetahuan Alam (IPA) merupakan salah satu mata pelajaran pokok yang ada di jenjang Sekolah Dasar (SD). IPA merupakan usaha manusia dalam memahami alam semesta melalui pengamatan yang tepat pada sasaran, serta menggunakan prosedur, dan dijelaskan dengan penalaran sehingga mendapatkan suatu kesimpulan Susanto (2013). Hakikat pembelajaran IPA yang didefinisikan sebagai ilmu tentang alam dapat diklasifikasikan menjadi tiga bagian yaitu ilmu pengetahuan alam sebagai produk, proses, dan sikap. Pembelajaran IPA di sekolah dasar diharapkan mampu menumbuhkan sikap ilmiah seperti seorang ilmuan. Sikap ilmiah dapat dikembangkan melalui kegiatan-kegiatan siswa dalam pembelajaran IPA pada saat melakukan diskusi, percobaan, simulasi, dan kegiatan proyek di lapangan Susanto (2013). Purwanti (2015) menyatakan, pembelajaran IPA pada umumnya di SD hanya berorientasi pada produk semata, sedangkan proses dan sikap ilmiah siswa untuk mencapai produk tersebut kurang diperhatikan. Sikap ilmiah merupakan salah satu komponen sikap yang wajib mulai dikembangkan pada jenjang sekolah dasar khususnya pada mata pelajaran IPA. Sikap ilmiah memiliki peran tersendiri dalam memotivasi diri siswa agar aktif dalam pembelajaran IPA, karena dengan memiliki sikap ilmiah siswa akan terdorong untuk mengikuti pembelajaran dan mampu menggali lebih jauh pembelajaran dengan rasa ingin tahu yang dimilikinya. Namun kenyataannya nampak penanaman sikap ilmiah pada siswa dalam pembelajaran IPA di jenjang SD khususnya SD di Gugus II Kecamatan Kubutambahan belum optimal. Maka dari perlu dilakukan perbaikan dan pembaharuan pada proses pembelajaran. Salah satu pembaharuan yang dapat dilakukan yaitu dengan 
menerapkan model pembelajaran yang sesuai dengan karakteristik siswa sekolah dasar. Salah satu alternatif dalam perbaikan dan pembaharuan pada proses pembelajaran yang sesuai dengan permasalahan tersebut dengan menggunakan model pembelajaran kooperatife tipe Team Games Tournament.

Model pembelajaran TGT (Team Games Tournament) sangat cocok diterapkan di sekolah dasar karena model pembelajaran ini sesuai dengan karakteristik siswa di sekolah dasar Rusman (2014) mengemukakan "TGT adalah salah satu tipe pembelajaran kooperatif yang menempatkan siswa dalam kelompok-kelompok belajar yang beranggotakan 5 sampai 6 orang siswa yang memiliki kemampuan, jenis kelamin, dan suku kata atau ras yang berbeda". Memurut Sohimin (2014), pembelajaran TGT terdiri dari lima komponen, yaitu penyajian kelas, belajar dalam kelompok (team), permainan (game), pertandingan (tournament), dan penghargaan kelompok (team recognition). Pada penelitian ini penerapan model pembelajaran tipe TGT (Team Games Tournament) yaitu dengan seting Lesson study. Lesson Study merupakan suatu proses dalam meningkatkan profesionalitas guru-guru di Jepang dengan jalan mengamati praktik mengajar mereka sendiri dengan dibantu oleh teman sejawatnya supaya cara mengajar guru menjadi lebih efektif. Dalam metode diperlukan kerjasama beberapa guru, masing-masing guru berperan sebagai penyusun rencana pembelajaran, praktikan, dan pengamat Mulyatiningsih (2014). Lesson Study terdiri dari beberapa tahap yaitu "Plan-Do-See" Masaaki (2014). Berdasarkan hal tersebut maka dilakukan penelitian yang berjudul "Pengaruh Model Pembelajaran TGT (Team Games Tournament) dengan Seting Lesson Study Terhadap Sikap IImiah Siswa Kelas IV Semester Genap Gugus II Kecamatan Kubutambahan".

\section{Metode}

Penelitian ini akan dilaksanakan di SD Gugus II Kecamatan Kubutambahan Kabupaten Buleleng. Waktu pelaksanaan penelitian ini dilaksanakan pada Semester Genap Tahun Pelajaran 2018/2019. Penelitian ini dikategorikan ke penelitian eksperimen semu (quasi eksperiment) dengan rancangan non-equivalent kontrol group design. Secara prosedural desain penelitian ini disajikan dalam Gambar 1 berikut ini.

\begin{tabular}{|lll|}
\hline$E: 01$ & $X$ & 02 \\
\hline$K: 03$ & - & 04 \\
\hline
\end{tabular}

Gambar 1. Desain Penelitian Non Equivalent Control Group Design

(Gall dalam Agung, 2014:53)

Populasi adalah keseluruhan dari obyek yang digunakan dalam suatu penelitian Agung (2014:69). Populasi penelitian ini yaitu seluruh siswa kelas IV di SD Gugus II Kecamatan Kubutambahan yaitu SD N 1 Kubutambahan, SD N 2 Kubutambahan, SD N 3 Kubutambahan, SD N 4 Kubutambahan, SD N 5 Kubutambahan, SD N 6 Kubutambahan, SD N 7 Kubutambahan. Jumlah total populasi sebanyak 194 siswa, jumlah populasi diperoleh dari seluruh siswa kelas IV dari tujuh SD di Gugus II Kecamatan Kubutambahan. Bagian dari populasi yang diambil yang akan dijadikan sebagai objek penelitian disebut dengan sampel. Sampel adalah sebagian dari populasi yang diambil yang dianggap mewakili seluruh populasi dan diambil dengan menggunakan teknik tertentu Agung (2014). Teknik pengambilan sampel yang digunakan pada penelitian ini yaitu cluster random sampling. Cluster random sampling yaitu pengambilan sampel dengan cara diundi. Setelah dilakukan pengundian terhadap 7 sekolah di gugus II Kecamatan Kubutambahan diperoleh bahwa kelompok eksperimen yang terpilih adalah kelas IV SD N 1 Kubutambahan berjumlah 39 siswa dan kelompok kontrol yang terpilih adalah kelas IV SD N 6 berjumlah 33 siswa. Suatu konsep yang sangat penting dalam penelitian disebut dengan variabel. Sesuatu yang dipilih oleh peneliti yang menjadi objek perhatian yang akan dipelajari oleh peneliti sehingga 
diperoleh informasi tentang hal tersebut kemudian ditarik kesimpulannya disebut variabel. Variabel penelitian ini dijelaskan bahwa terdapat dua variabel yaitu variabel bebas (model pembelajaran Teams Games Tournament dengan seting lesson study) dan variabel terikat (sikap ilmiah). Model pembelajaran TGT adalah model yang mengajak siswa belajar sambil bermain. TGT adalah salat satu tipe pembelajaran kooperatif yang menempatkan siswa dalam kelompok-kelompok belajar yang beranggotakan 5-6 orang siswa yang memiliki kemampuan, jenis kelamin, dan suku kata atau ras yang berbeda (Rusman, 2014).

Sikap adalah kecenderungan untuk melakukan sesuatu dengan cara metode, pola, dan teknik tertentu terhadap dunia sekitarnya baik berupa individu-individu maupun objekobjek tertentu. Sikap ilmiah dapat dikembangkan melalui kegiatan-kegiatan ilmiah seperti pada saat melakukan diskusi, percobaan, simulasi, dan kegiatan proyek. Sikap ilmiah harus terus didukung, dipupuk, dan dikembangkan sehingga dapat dimiliki dalam diri siswa.

Data yang dianalisis dalam penelitian ini adalah data hasil belajar IPA siswa, dan untuk mendapat data tersebut digunakan non tes berupa kuesioner sikap ilmiah. Sebelum tes digunakan terlebih dahulu dilakukan mengujian instrumen yang meliputi:

Pertama uji validitas yang meliputi: (1) validitas isi berkenan dengan kesanggupan alat penilaian dalam mengukur cakupan substansi yang seharusnya. Artinya, instrumen tersebut mampu mengungkap isi variabel yang hendak diukur. (2) validitas butir ini dilakukan untuk mengetahui kebenaran setiap butir alat penilaian. Untuk mengukur validitas butir kuesioner menggunakan rumus korelasi product moment. Skor yang diperoleh kemudian dibandingkan dengan skor yang diperoleh dari $r_{\text {tabel }}$, dengan taraf signifikansi $5 \%$. Jika $r_{\text {hitung }}>r_{\text {tabel }}$ berarti valid dan jika $r_{\text {hitung }}<r_{\text {tabel }}$ berarti tidak valid. Dari 35 pernyataan yang telah diuji cobakan maka diperoleh 5 pernyataan tidak valid dan 30 pernyataan yang valid.

Kedua, reliabilitas rumus yang digunakan adalah Kuder Richardson 20 (KR-20). Dari 30 soal yang dinyatakan valid dan memiliki kriteria maka diperoleh $r_{1.1}=0,88$ artinya bahwa kuesioner pada penelitian ini tergolong reliabel dengan kriteria derajat reliabilitas sangat tinggi.

Data hasil sikap ilmiah IPA yang telah terkumpul dianalisis menggunakan uji-t. Sebelum dianalisis terlebih dahulu dilakukan uji prasyarat analisis data yaitu: (1) uji normalitas sebaran data menggunakan rumus chi-kuadrat adapun kriteria pengujian adalah jika $\chi_{\text {hitung }}^{2}<\chi_{\text {tabel }}^{2}$ Pada taraf signifikansi $5 \%$ dengan $\mathrm{dk}=5$ diperoleh bahwa data berdistribusi normal. (2) uji homogenitas varians, kriteria pengujian homogenitas varians jika $F_{\text {hitung }}>F_{\text {tabel }}$ maka kriteria pengujian homogenitas dikatakan homogen.

Uji hipotesis pada penelitian ini menggunakan uji-t dengan rumus separated varians. Dengan kriteria jika $t_{\text {hitung }}>t_{\text {tabel }}$ pada taraf signifikansi $5 \%$ dengan $d k=n_{1}+n_{2}-2$, maka $H_{0}$ diterima.

\section{Hasil dan Pembahasan}

Berdasarkan data sikap ilmiah IPA, dianalisis menggunakan analisis statistik deskriptif agar dapat mengetahui mean, median, modus, standar deviasi, dan varians, dari data hasil pre test dan post test pada kelompok eksperimen dan kelompok kontrol. Rangkuman hasil analisis data statistik deskriptif pre test pada kelompok eksperimen dapat dilihat pada Tabel 1 berikut ini:

Tabel 1. Deskriptif data pre test sikap ilmiah IPA kelompok eksperimen

\begin{tabular}{lcc}
\hline & Statistik & Sikap limiah IPA \\
\hline Mean & 103,87 \\
Median & 104,7 \\
Modus & 106,17 \\
Standar Deviasi & 11,35 \\
Varians & 128,90 \\
\hline
\end{tabular}


Data skor sikap ilmiah dapat disajikan ke dalam bentuk grafik poligon pada gambar 02 sebagai berikut.

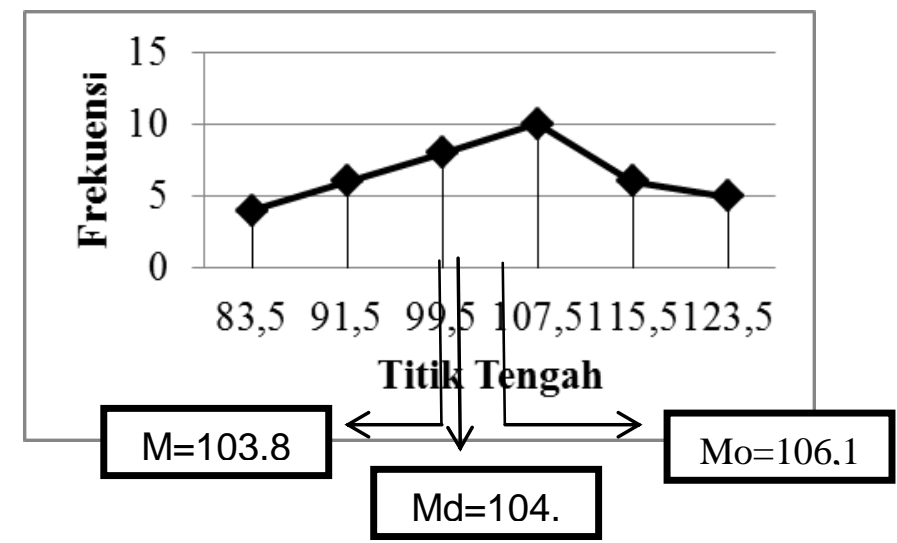

Gambar 2. Grafik Histogram Data Sikap IImiah Siswa Kelompok Eksperimen

Berdasarkan Gambar garfik poligon di atas dapat diketahui bahwa $\mathrm{M}<\mathrm{Md}<\mathrm{Mo}$. Sehingga membentuk grafik juling negatif. Selanjutnya rata-rata skor pre test sikap ilmiah siswa kelompok eksperimen dengan $M=103,87$ dikonversi dalam skala penilaian yang berada pada kategori tinggi. berikut.

Data sikap ilmiah IPA pre test kelompok kontrol disajikan pada Tabel 2. Sebagai

Tabel 2. Deskriptif data pre test sikap ilmiah IPA kelompok eksperimen

\begin{tabular}{lcc}
\hline & Statistik & Sikap limiah IPA \\
\hline Mean & 98,52 \\
Median & 98,06 \\
Modus & 95,83 \\
Standar Deviasi & 11,25 \\
Varians & 126,45 \\
\hline
\end{tabular}

Data skor sikap ilmiah dapat disajikan ke dalam bentuk grafik poligon pada gambar 03 sebagai berikut.

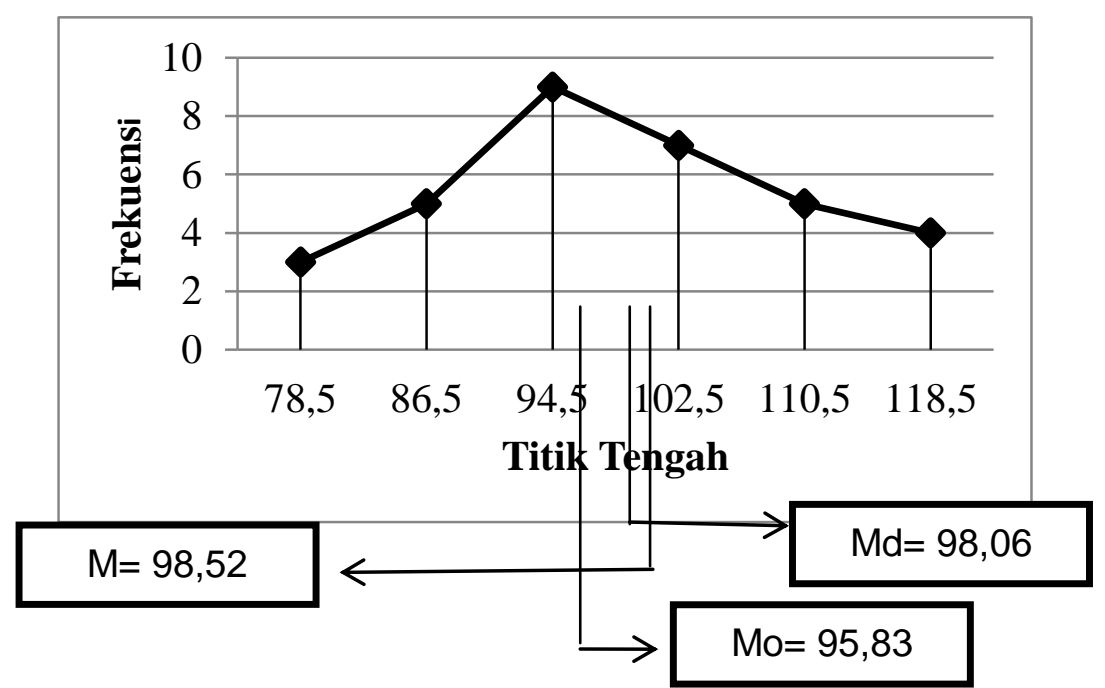

Gambar 3. Grafik Poligon Data Sikap Ilmiah Siswa Kelompok Kontrol 
Berdasarkan Gambar garfik poligon di atas dapat diketahui bahwa $\mathrm{M}>\mathrm{Md}>\mathrm{Mo}$. Sehingga membentuk grafik juling positif. Selanjutnya rata-rata skor pre test sikap ilmiah siswa kelompok eksperimen dengan $\mathrm{M}=98,52$ dikonversi dalam skala penilaian yang berada pada kategori sedang. berikut.

Data sikap ilmiah IPA post test kelompok eksperimen disajikan pada Tabel 3. Sebagai

Tabel 3. Deskriptif data pot test sikap ilmiah IPA kelompok eksperimen

\begin{tabular}{lcc}
\hline & Statistik & Sikap limiah IPA \\
\hline Mean & 126,85 \\
Median & 129 \\
Modus & 129,56 \\
Standar Deviasi & 9,52 \\
Varians & 90,66 \\
\hline
\end{tabular}

Data skor sikap ilmiah dapat disajikan ke dalam bentuk grafik poligon pada gambar 04 sebagai berikut.

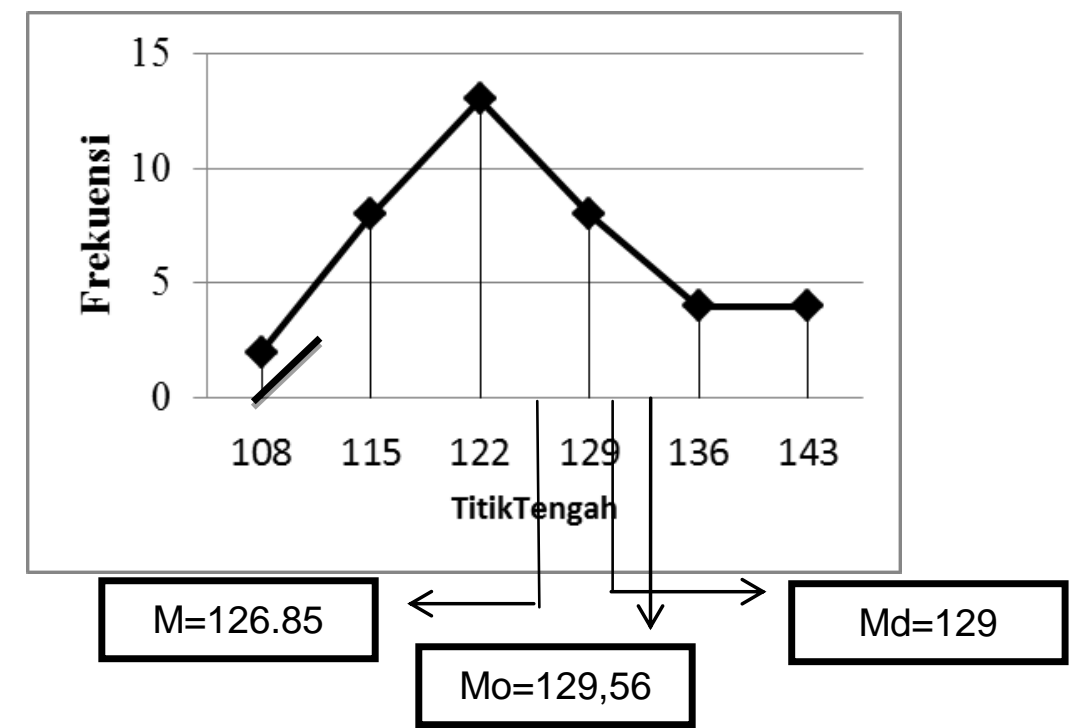

Gambar 4. Grafik Poligon Data Sikap IImiah Siswa Kelompok Eksperimen

Berdasarkan Gambar garfik poligon di atas dapat diketahui bahwa $\mathrm{M}<\mathrm{Md}<\mathrm{Mo}$. Sehingga membentuk grafik juling negatif. Selanjutnya rata-rata skor post test sikap ilmiah siswa kelompok eksperimen dengan $M=126,85$ dikonversi dalam skala penilaian yang berada pada kategori sangat tinggi. berikut.

Data sikap ilmiah IPA post test kelompok kontrol disajikan pada tabel 04. Sebagai

Tabel 4. Deskriptif data pot test sikap ilmiah IPA kelompok control

\begin{tabular}{cc}
\hline Statistik & Sikap limiah IPA \\
\hline Mean & 126,85 \\
Median & 129 \\
Modus & 129,56 \\
Standar Deviasi & 9,52 \\
Varians & 90,66 \\
\hline
\end{tabular}


Data skor sikap ilmiah dapat disajikan ke dalam bentuk grafik poligon pada gambar 04 sebagai berikut.

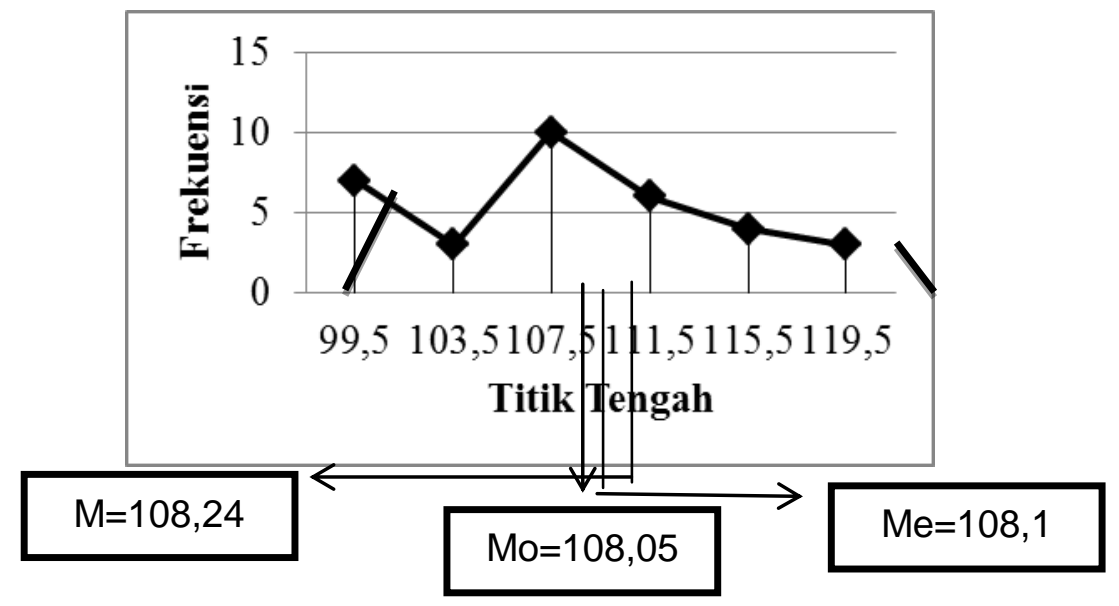

Gambar 5. Grafik Histogram Data Sikap IImiah Siswa Kelompok Kontrol

Berdasarkan garfik poligon di atas dapat diketahui bahwa $M>M d>M o$. Sehingga membentuk grafik juling positif. Selanjutnya rata-rata skor post test sikap ilmiah siswa kelompok eksperimen dengan $\mathrm{M}=108,24$ dikonversi dalam skala penilaian yang berada pada kategori tinggi.

Data sikap ilmiah yang sudah terkumpul dianalisis menggunakan uji-t. Sebelum dianalisis terlebih dahulu dilakukan uji prasyarat yang meliputi uji normalitas sebaran data dan uji homogenitas varians. Hasil analisis uji normalitas sebaran data pre test dan post test kelompok ekperimen dan kelompok kontrol disajikan ke dalam tabel 05 sebagai berikut.

Tabel 5. Hasil Uji Normalitas Sebaran Data

\begin{tabular}{ccccc}
\hline No & Kelompok Data Sikap IImiah & $\chi^{2}$ hitung & $\chi^{2}$ tabel & Keterangan \\
\hline 1 & Pre Test Eksperimen & 2,08 & 11,070 & Normal \\
2 & Pre Test Kontrol & 1,41 & 11,070 & Normal \\
3 & Post Test Eksperimen & 1,44 & 11,070 & Normal \\
4 & Post Test Kontrol & 4,53 & 11,070 & Normal \\
\hline
\end{tabular}

Berdasarkan tabel di atas dapat dilihat bahwa skor data pre test dan post test kelompok ekperimen dan kelompok kontrol berdistribusi normal. Hasil analisis uji homogenitas varians pre test dan post test kelompok ekperimen dan kelompok kontrol disajikan ke dalam Tabel 6 sebagai berikut.

Tabel 6. Hasil Uji Normalitas Sebaran Data

\begin{tabular}{|c|c|c|c|c|c|c|}
\hline No & \multicolumn{3}{|c|}{ Kelompok Data Sikap IImiah } & $F_{\text {hitung }}$ & $F_{\text {tabel }}$ & Keterangan \\
\hline 1 & $\begin{array}{l}\text { Pre Test Kelom } \\
\text { Kontrol }\end{array}$ & pok Ek & rimen dan & 1,02 & 3,98 & Homogen \\
\hline 2 & $\begin{array}{l}\text { Pre Test } \\
\text { Eksperimen dan }\end{array}$ & Kontrol & Kelompok & 1,96 & 3,98 & Homogen \\
\hline
\end{tabular}

Hal ini berarti, uji homogenitas varians data sikap ilmiah pre test dan post test kelompok ekperimen dan kelompok kontrol adalah homogen. Setelah diperoleh hasil dari uji prasyarat analisis data, dilanjutkan dengan pengujian hipotesis penelitian. Pengujian hipotesis tersebut dengan menggunakan analisis uji-t. Sebelum melakukan analisis uji-t 
dilakukan analisis gain score dari data pre test dan post test sikap ilmiah siswa kelompok eksperimen dan kelompok kontrol. Ringkasan uji hipotesis disajikan pada Tabel 7 sebagai berikut.

Tabel 7. Ringakasan Hasil Uji Hipotesisi

\begin{tabular}{lccccccc}
\hline Kelompok & $\mathbf{S}^{2}$ & $\overline{\mathrm{X}}$ & $\mathbf{N}$ & $\mathbf{D k}$ & $\mathbf{t}_{\text {hitung }}$ & $\mathbf{t}_{\text {tabel }}$ & Kesimpulan \\
\hline Eksperimen & 0,052 & 0,475 & 39 & 70 & 9,563 & \multirow{2}{*}{1,994} & \multirow{2}{*}{$\mathrm{H}_{0}$ ditolak } \\
Kontrol & 0,014 & 0,169 & 33 & & & \\
\hline
\end{tabular}

Berdasarkan Tabel di atas menunjukkan bahwa $t_{\text {hitung }}>t_{\text {tabel }}$ sehingga $\mathrm{H}_{0}$ ditolak dan $\mathrm{H}_{1}$ diterima. Jadi dapat disimpulkan bahwa terdapat pengaruh yang signifikan model pembelajaran TGT (Teams Games Tournament) dengan seting Lesson Study terhadap sikap ilmiah siswa kelas IV semester II di SD Gugus II Kecamatan Kubutambahan. Model pembelajaran TGT memiliki lima tahapan yaitu penyajian kelas, belajar dalam kelompok, permainan, pertandingan, dan pehargaan kelompok. Penanaman sikap ilmiah akan nampak pada langkah-langkah dari model pembelajaran TGT.

Tahap pertama penyajian kelas, pada tahap ini guru menyajikan secara singkat materi yang akan dibahas. Sikap ilmiah yang mampu dikembangkan adalah sikap rasa ingin tahu. Hal ini nampak pada saat guru menyajikan secara singkat materi atau topik yang dibahas, siswa mencatat hal-hal yang dianggap penting dan terdapat beberapa siswa yang mampu bertanya maupun menjawab pertanyaan dari guru.

Tahap kedua belajar dalam kelompok mampu mengembangkan sikap berpikiran terbuka, respek terhadap data, dan rasa ingin tahu. Sikap berpikiran terbuka nampak pada saat pembagian kelompok, siswa menerima siapa saja yang menjadi anggota kelompoknya tanpa membedakan latar belakang temannya. Membentuk siswa belajar kelompok dapat memberikan pengalaman langsung untuk melatih siswa berdiskusi bersama anggota kelompoknya. Temuan tersebut sesuai dengan pendapat Indrani (2017) pembelajaran berkelompok mampu mendiskusikan topik yang sudah diberikan oleh guru dengan saling bertukar pikiran maupun informasi dengan anggota kelompok lainnya. Pada tahap ini sikap ilmiah yang mampu dikembangkan yaitu sikap rasa ingin tahu. Sikap rasa ingin tahu terlihat pada saat siswa melakukan pratikum yang belum pernah dilakukan sebelumnya, siswa sangat aktif dan antusias pada saat melakukan pratikum, apabila pratikum yang sudah dilakukan gagal siswa tersebut akan terus mengulangi sampai partikum yang dilakukan tersebut benar-benar berhasil. Hal tersebut menunjukkan bahwa siswa sudah mampu mengembangkan sikap rasa ingin tahunya. Hal ini sejalan dengan temuan Widiadnyana (2014) bahwa sikap rasa ingin tahu siswa berkembang ketika siswa melakukan eksperimen. Sikap ilmiah yang mampu dikembangkan pada tahap ini yaitu respek terhadap data. Sikap respek terhadap data terlihat pada saat siswa membuat laporan hasil diskusi maupun hasil dari pratikum yang sudah dilakukan, siswa membuat laporan sesuai dengan pengamatan yang sudah dilakukan dan menyajikan laporan sesuai dengan apa yang telah dibuatnya.

Tahap ketiga permainan (games), pada tahap ini mampu menumbuhkan sikap rasa ingin tahu dan sikap berpikiran terbuka. Sikap rasa ingin tahu dan sikap berpikiran terbuka nampak pada saat siswa mengikuti game, siswa mampu menggali informasi yang telah didapatkan selama mengikuti pelajaran dan siswa mampu menghargai antar kelompok yang menjawab pertanyaan maupun yang menambahkan jawaban. Pada tahap permainan ini siswa sangat antusias dan mampu membuat suasana kelas menjadi menyenangkan. Hal ini sejalan dengan temuan Putri (2017) menyatakan bahwa Games dapat menghidupkan situasi pembelajaran. Siswa sangat antusias dalam mengikuti permainan sekaligus berkompetisi dalam permainan tersebut. Kompetisi dan persaingan dapat meningkatkan motivasi siswa untuk berusaha menjawab pertanyaan dalam permainan yang diberikan.

Tahap keempat pertandingan (Tournament), pada tahap ini mampu mengembangkan sikap rasa ingin tahu dan sikap berpikiran terbuka. Sikap rasa ingin tahu dan sikap berpikiran terbuka nampak pada saat siswa mengikuti pertandingan sama halnya seperti pada tahap 
permainan. Pada tahap pertandingan ini siswa sangat antusias dan mampu bersaing secara sehat yaitu mampu menghargai jawaban dari kelompok lain yang mengikuti pertandinga. Hal tersebut sejalan dengan pendapat Munawir (2018) bahwa model TGT digunakan dalam turnamen akademik, siswa mampu bersaing dengan tim yang lainnya.

Tahap kelima penghargaan kelompok, pada tahap ini guru mengumumkan kelompok yang menang dan memberikan penghargaan kepada kelompok yang mendapatkan juara pada saat mengikuti pertandingan. Penghargaan kelompok ini dilakukan agar siswa termotivasi dan lebih semangat dalam mengikuti proses pembelajaran.

Berdasarkan pemaparan kegiatan model pembelajaran TGT di atas menunjukkan bahwa model pembelajaran TGT mampu membuat suasana pembelajaran lebih efektif dan menyenangkan. Dalam pembelajaran siswa tidak hanya fokus untuk belajar saja tapi diselingi dengan permainan agar siswa tidak bosan dalam mengikuti proses pembelajaran. Selain itu model pembelajaran TGT mampu meningkatkan kerjasama dan interaksi antar siswa. Hal ini sejalan dengan temuan putri (2017) menyatakan bahwa model pembelajaran kooperatif tipe Team Games Tournament (TGT) dapat meningkatkan interaksi dan kerjasama siswa dalam kelompok. Selain menerapkan model pembelajaran TGT, hal yang ikut berperan penting dalam penelitian ini yaitu diterapkannya lesson study.

Penerapa lesson study dapat meningkatkan kemampuan guru dalam merancang, melaksanakan, dan mengevaluasi pembelajaran karena guru berkolaborasi dengan tim lesson study untuk dapat memperbaiki proses pembelajaran yang menyenangkan bagi siswa sehingga dapat mengembangkan sikap ilmiah siswa. Lesson study memiliki tiga tahapan yaitu perencanaa (plan), pelaksanaa (do), dan refleksi (see). Pada tahap perencanaa (plan) guru bersama tim lesson study merancang perangkat pembelajaran seperti RPP, LKPD, media pembelajaran, dan mempelajari model pembelajaran yang akan diterapkan. Pada tahap pelaksanaa (do) guru model mengajar dan tim lesson study yang lain mengamati proses pembelajaran. Pada tahap pelaksanaa $(d o)$ terdapat beberapa temuan berupa siswa lebih bersemangat untuk mengikuti pembelajaran, masih ada beberapa siswa yang lain-lain saat mengadakan diskusi kelompok. Pada tahap refleksi (see) guru beserta tim lesson study melakukan diskusi untuk membahas temuan-temuan selama proses pembelajaran berlangsung agar dapat melaksanakan perbaikan pada pembelajaran berikutnya. Berdasarkan pada tahapan-tahapan yang dilakukan oleh tim lesson study tersebut dapat menjadikan guru lebih baik dalam melaksanakan proses pembelajaran di kelas seperti guru mampu lebih cepat tanggap jika ada siswa yang pasif, guru dapat mengembangkan sikap ilmiah siswa dalam proses pembelajaran. Pada penelitian ini pada saat penerapan lesson study sudah berjalan dengan optimal yaitu guru dan tim lesson study sudah mampu bekerjasama dengan baik dalam merancang, melaksanakan, maupun mengevaluasi proses pembelajaran. Temuan tersebut didukung oleh teori Mulyaningsih (2014) yaitu dalam metode diperlukan kerjasama beberapa guru, masing-masing guru berperan sebagai penyusun rencana pembelajaran, praktikan, dan pengamat.

Berbeda dengan kelas kontrol yang diterapkan menggunakan model pembelajaran konvensional yang masih berpusat pada guru, guru cenderung lebih banyak mendominasi kegiatan pembelajaran. Pada saat proses pembelajaran berlangsung siswa cenderung pasif, lebih banyak mencatat, dan mengerjakan tugas. Hal tersebut menyebabkan siswa merasa kesulitan untuk memahami materi pelajaran dan cenderung bosan dan kurangnya minat dan motivasi siswa dalam mengikuti proses pembelajaran.

Hasil penelitian ini memiliki persamaan dengan temuan dari beberapa penelitian sebelumnya yang relevan dan memperkuat hasil penelitian yng diperoleh, hal tersebut didukung oleh hasil penelitian Cahyaningsih (2017), Ibrahim \& Hidayati (2014), Munawir, dkk (2018), Faris, dkk (2018), dan Nugroho (2018). Dari beberapa hasil penelitian yang relevan tersebut menyatakan bahwa model pembelajaran TGT sangat berpengaruh baik dalam proses pembelajaran.

Berdasarkan dari pemaparan tersebut, dapat disimpulkan bahwa model pembelajaran TGT (Teams Games Tournament) dengan seting lesson study berpengaruh terhadap sikap ilmiah siswa kelas IV SDN Gugus II Kecamatan Kubutambahan. 


\section{Simpulan dan Saran}

Berdasarkan rata-rata skor pre test dan skor post test kelompok eksperimen dan kelompok kontrol yaitu rata-rata pre test kelompok eksperimen sebesar 103,87, pada skala penilaian berada pada kategori tinggi. Sedangkan rata-rata skor pre test kelompok kontrol yaitu 98,52 yang berada pada kategori sedang. Rata-rata skor post test kelompok eksperimen adalah 126,85 yang berada pada kategori sangat tinggi. Sedangkan rata-rata skor post test kelompok kontrol adalah 108,24 yang berada pada kategori tinggi.

Hasil analisis uji-t diperoleh $t_{\text {hitung }}$ sebesar 9,563 dan $t_{\text {tabel }}$ pada taraf siginifikansi $5 \%$ dengan $d k=70$ adalah 1,994. Hal ini menunjukkan $t_{\text {hitung }}>t_{\text {tabel }}$ sehingga $H_{0}$ ditolak dan $H_{1}$ diterima. Jadi dapat disimpulkan bahwa terdapat perbedaan yang signifikan siswa yang dibelajarkan menggunakan model pembelajaran TGT (Teams Games Tournament) dengan Seting Lesson Study dengan siswa yang tidak dibelajarkan menggunakan model pembelajaran TGT (Teams Games Tournament) dengan Seting Lesson Study. Adanya perbedaan yang signifikan tersebut menunjukkan bahwa terdapat pengaruh model pembelajaran TGT (Teams Games Tournament) dengan Seting Lesson Study terhadap sikap ilmiah siswa kelas IV Semester II di SD Gugus II Kecamatan Kubutambahan.

Adapun saran yang dapat disampaikan guna peningkatan kualitas pembelajaran IPA di sekolah dasar yaitu Disarankan kepda siswa agar terlibat secara aktif dalam proses pembelajaran IPA sehingga sikap ilmiah dapat berkembang secara optimal.

Disarkankan kepada guru agar dapat melanjutkan model pembelajaran TGT (Team Games Tournament) sehingga sikap ilmiah siswa dapat dikembangkan.

Disarankan kepada kepala sekolah agar hasil penelitian ini dapat dijadikan dasar untuk mengambil kebijakan yang tepat dalam membina guru-guru yang menjadi binaannya, sehingga guru memiliki kemampuan profesional yang tinggi.

Disarankan kepada peneliti lain agar melakukan lanjutan yang sejalan dengan penelitian ini.

\section{Daftar Pustaka}

Agung, A. A. G. 2014. Metodologi Penelitian Pendidikan. Malang: Aditya Media Publishing.

Cahyaningsih, U. 2017. "Pengaruh Model Pembelajaran Kooperatif Tipe TGT (Teams Games Tournament) terhadap Hasil Belajar Matematika Siswa SD”. Jurnal Ckrawala Pendas Vol. 3 No. 1.

Faris, dkk. 2018. "The Effectiveness of Teams Games Tournament with Biodomino on Ecosystem Material to Enhance Student's Activity and Learning Outcomes in Salatiga". Junal of Biology Education.

Ibrahim \& Hidayati. 2014. "Pengaruh Model Pembelajaran Teams Games Tournament terhadap Peningkatan Kemampuan Pemecahan Masalah Matematika ditinjau dari Kemampuan Awal Siswa SMA Negeri 1 Seyegan”. Jurnal Argi Sains Vol. 5 No. 2.

Masaaki, Sato. 2014. "Dialog dan Kolaborasi di Sekolah Menengah Pertama Praktek "Learning Community". Japan Internasional Cooperation Agency.

Mulyatiningsih, E. 2014. Metode Penelitian Terapan Bidang Pendidikan. Bandung: Alfabeta.

Munawir A, dkk. 2018. "The Influence of Using Teams-Games-Tournament (TGT) on Simple Present Tense". Journal of English Edocation and Development Vol. 1 No. 2 p-ISSN: 2597-713. 
Nugroho \& Radia. 2018. "Improving the Natural Science Learning Result through the Implementation of Teams Games Tournament Learning Model Aided with Video Learning". Journal of Educational Science and Technology Vol. 4 No. 1.

Prasetyo, H. 2018. "Telaah klasifikasi Aspek dan Arah Perkembangan Riset”. Jurnal Teknik Industri Vol. 13, No. 1.

Rusman. 2014. Model-model Pembelajaran: Mengembangkan Profesionalisme Guru. Jakarta: PT. Raja Grafindo Persada.

Sohimin, A. 2014. 68 Model Pembelajaran Inovatif dalam Kurikulum 2013. Yogyakarta: AR.RUZZ. Media.

Susanto, A. 2013. Teori Belajar Pembelajaran di Sekolah Dasar. Jakarta: Prenadamedia Group.

Indrani, P. A. M. 2017. "Pengaruh Model Pembelajaran Kooperatif Group Investigation Terhadap Kemampuan Berpikir Kritis IPA Siswa Kelas V". Singaraja: e-journal Mimbar PGSD Universitas Pendidikan Ganesha. Singaraja, e-journal Mimbar PGSD Universitas Pendidikan Ganesha Vol.3 No. 1.

Widiadnyana, I. W. 2014. "Pengaruh Model Discovery Learning Terhadap Pemahaman Konsep IPA dan Sikap IImiah Siswa SMP”. e-journal Program Pscasarjana Universitas Pendidikan Ganesha Program Studi IPA Vol. 4.

Kusumaningrum, P. C. A. 2014. "Pengaruh Model Pembelajaran Kooperatif Tipe Team Games Tournament (TGT) Terhadap Hasil Belajar IPA pada Siswa Kelas V Gugus XV Kecamatan Buleleng Tahun Ajaran 2013/2014". e-journal Mimbar PGSD Universitas Pendidikan Ganesha Jurusan PGSD Vol. 2 No. 1. 